\title{
Tourism Marketing Strategy Based on Superior Potential of Pelaga Tourism Village, Petang District, Badung Regency
}

\author{
I Ketut Suarja ${ }^{1, *}$, Nyoman Indah Kusuma Dewi², I Gusti Agung Bagus Mataram ${ }^{1}$ \\ ${ }^{1}$ Tourism Department, ${ }^{2}$ Business Administration Department \\ Bali State Polytechnic \\ Badung, Indonesia \\ *ketutsuarja@pnb.ac.id,ikdewi@pnb.ac.id, mataram@pnb.ac.id
}

\begin{abstract}
Tourism marketing strategy for a tourism village differs from other tourist destinations. Tourism village marketing not primarily to earn profit but also focus on community welfare. Pelaga Tourism Village has various superior potential that can be explored further and need to be marketed to invite visitors. This study aims to recognize the Pelaga Tourism Village current position and formulate a marketing strategy of superior potential tourist attractions to increase the number of tourists. The study was conducted qualitatively to develop a tourism marketing strategy for existing superior potential in Pelaga. Data collection techniques were done by using in-depth interviews, observation and documentation. The informant for interviews were stakeholders of Pelaga Tourism Village. The strengths, weaknesses, opportunities and threats of internal and external factors related to Pelaga Tourism Village were identified in a focus group discussion. Position was determined with calculating the Internal Factor Analysis Strategy and External Factor Analysis Strategy score. The marketing strategy was proposed based on SWOT analysis. The main outcome of this study is a marketing strategy of Pelaga Tourism Village.
\end{abstract}

Keywords-tourism marketing strategy, tourism village, SWOT Analysis, IFAS, EFAS

\section{INTRODUCTION}

The tourism sector has contributed and played a strategic role in various fields of development as well as improving people's welfare. Tourism development in Indonesia has objectives to: (1) Increase economic growth; (2) Improve welfare; (3) Eliminate poverty; (4) Tackle unemployment; (5) Preserve nature, the environment, and natural resources; (6) Promote culture; (7) Elevate the nation's image; (8) Foster a sense of love for Indonesia; (9) Strengthen national identity and unity; and (10) Strengthen friendship between nations. Based on Regent Regulation No. 47 of 2010, there are 11 villages designated as tourist villages, namely Bongkasa Pertiwi, Pangsan, Kerta, Pelaga, Belok, Carang Sari, Sangeh, Baha, Kapal, Mengwi, and Munggu. Based on studies conducted by local government, most of designated tourism village are undeveloped. The failure of development of a tourism village mainly caused by: (1) The wrong perspective on the existence of a tourist village; (2) Lack of socialization and guidance on tourism villages; (3) There has not been any coordination between the management at the village level; (4) The problem of capital, institutional management, and human resources; (5) Tourist visits have not matched expectations; (6) Forcing products and tourist attractions not according to their potential; (7) High hopes that the tourism village will soon and quickly bring in money; (8) At the implementation level, the local government seems detached; and (9) Marketing and promotion are not going well. Based on the results of the study, there are two tourism villages, namely Belok Sidan Tourism Village and Pelaga Tourism Village which are considered to have been running in the sense that they already have planning, sustainable management institutions, human resources, capital, tourism products and attractions, tourism activities, tourist visits, promotions, and economic benefits that affect directly to local communities. In order to empower the tourism village, there is a need to improve the causes of the failure.

There is enormous research related to tourism village from different perspective namely Community Based Tourism (CBT) $[1,2]$, strategy development [3], economic impact [4, 5, $6,7]$, social impact $[5,8,9]$, the role of stakeholders $[10,11]$, supply chain [12], and community empowerment [13, 14]. However, there is none discussing about the marketing strategy of superior potential of a tourism village. Therefore, the research was undertaken to fill in this gap.

Pelaga Tourism Village is considered well managed in terms of having strategic planning, formal organizations, potential human resources, sufficient fund, various tourism products and attractions, tourist activities, promotional campaign, and economic benefits for local community. Despite having these, Pelaga Tourism Village could not invite tourists as targeted. Therefore, formulating marketing strategy becomes crucial to improve the number of visitors. Potential tourist attractions in Pelaga Tourism Village are namely Nungnung Waterfall, Biah-biah Waterfall, Tukad Bangkung Waterfall, Asparagus Plantation, Pucak Mangu Temple, Penataran Agung 
Bukian Temple, and Agriculture and Culture Festival [15]. Thus, how to market these potentials is a challenge to Pelaga Tourism Village officials.

\section{RESEARCH METHOD}

This research was conducted in Pelaga Tourism Village, Petang District, Badung Regency. Pelaga Tourism Village was chosen as a research location based on its readiness to be marketed since having tourism products and attractions, and sales and marketing section in Pelaga Tourism Village organization. The research was approached through qualitative research in order to determine the marketing strategy of Pelaga Tourism Village. Data was collected by employing observation, interviews, questionnaires, and documentation. Observation was undertaken by looking closely to the operational of Pelaga Tourism Village [16]. Interviews and questionnaires were conducted to 8 members of the sales and marketing section of tourism village management [16]. Documentation regarding the village was studied as supporting data for the discussion [16]. Data was analysed utilizing the SWOT (Strengths, Weaknesses, Opportunities and Threats) analysis. Form the result of SWOT analyses the IFAS and EFAS matrices were calculated to determine the marketing strategy [17] and [18].

\section{RESULT AND DISCUSSION}

\section{A. Existing Marketing Mix Strategy}

The marketing mix strategy held by the sales and marketing department is in accordance with the 7P theory such as products, prices, places, promotions, people, processes, and physical evidence $[19,20,21,22,23,24]$. Tourism products of Pelaga Tourism Village are Asparagus Plants, Agricultural and Culture Festival, Nungnung Waterfall, Tukad Bangkung Waterfall, Biah-biah Waterfall, Tukad Bangkung Bridge, Penataran Agung Bukian Temple, Pucak Mangu Temple, Gumitir flower plants, various types of vegetable plants, sacred dances, traditional ceremonies, trekking paths, cycling track, campsites, and yoga. Pelaga Tourism Village offers affordable and competitive prices compares with other tourism village. Places are related to strategic location of Pelaga Tourism Village and tourism attraction such as asparagus plantation, the Tukad Bangkung Bridge which is the longest bridge in Bali and the highest in Asia, Nungnung Waterfall, and a place to relax while enjoying the natural panorama with mountains and valleys. The location of Pelaga Tourism Village is quite far from the crowded places so that all tourists can have time to relax. Promotion is done by going on sales trips and taking part in exhibitions by the sales and marketing team to introduce the potentials of Pelaga Tourism Village. People involves in managing Pelaga Tourism Village consisting of professional and well-trained marketing team. Process is the actual procedure, mechanism, and flow of activities used to provide services in Pelaga Tourism Village. Badung Regency Government collaborates with management of Pelaga to provide services to tourists. Physical Evidence of Pelaga
Tourism Village is demonstrated by offering adequate parking lot, clean environment, comfortable and safe jogging and cycling track, and keeping the environment with its natural.

\section{B. SWOT Analysis}

The result of the SWOT analysis of Pelaga Tourism Village are as follows.

1) Strengths: The strengths of Pelaga Tourism Village are strategic location with 4 regencies as a border, unique attractions, social cultural events, longest bridge in Bali, price selection for package tours, easy to reach tourist attractions, sufficient area, sufficient parking lot, promotion collaboration with Badung Regency, farmer's festival, social media promotion, joint exhibitions, competence staff, having marketing team, having partners/vendors (entertainment, flower girl, umbrella boy, videographer and photographer), availability of homestays, and quality of homestays.

2) Weaknesses: The weaknesses of Pelaga Tourism Village are limited food and beverage selection, have camping ground but very basic, difficulty in pricing, photo spots, public open space for waiting, ability for personal selling to prospective consumers, partner from travel agencies, and training center for asparagus farming.

3) Opportunities: The opportunities having by Pelaga Tourism Village are Bali's security and safety, stable inflation, development of communication technology (software application), development of Information Technology, community support, and local culture.

4) Threats: The threats are competitors with similar products/attractions, similar products/attractions, unpredictable political and economic circumstances, and consumers' purchasing power.

The result of SWOT Analysis then was analysed by utilizing the Internal and External Factor Analysis Strategy as the following.

\section{Summary of Internal and External Factor Analysis Strategy}

The weight of internal and external factors was the result of distributing questionnaires to 8 respondents from the marketing team with different results for each respondent. The weight of the internal and external factors was determined by the respondent based on the importance of each indicator to increase the sales of tour packages at Pelaga Tourism Village.

1) Summary of Internal Factor Analysis (IFAS): The IFAS analysis is to determine the total weighted value (score) and ratings of each indicator to obtain the total weighted value as in Table 1. 
TABLE I. INTERNAL FACTOR ANALYSIS STRATEGY (IFAS)

\begin{tabular}{|c|c|c|c|c|}
\hline No & $\begin{array}{c}\text { Internal Factor Analysis } \\
\text { Strategy }\end{array}$ & Weight & Rating & Score \\
\hline & Strengths: & & & \\
\hline 1 & $\begin{array}{l}\text { Strategic location with } 4 \\
\text { regencies as a border }\end{array}$ & 0,046 & 3,25 & 0,15 \\
\hline 2 & Unique attractions & 0,044 & 3,13 & 0,14 \\
\hline 3 & Social cultural events & 0,042 & 3,00 & 0,13 \\
\hline 4 & Longest bridge in Bali & 0,044 & 3,13 & 0,14 \\
\hline 5 & Price selection for package tours & 0,040 & 2,88 & 0,12 \\
\hline 6 & Easy to reach tourist attractions & 0,049 & 3,50 & 0,17 \\
\hline 7 & Sufficient area & 0,035 & 2,50 & 0,09 \\
\hline 8 & Sufficient parking lot & 0,040 & 2,88 & 0,12 \\
\hline 9 & $\begin{array}{l}\text { Promotion collaboration with } \\
\text { Badung Regency }\end{array}$ & 0,046 & 3,25 & 0,15 \\
\hline 10 & Farmer's festival & 0,039 & 2,75 & 0,11 \\
\hline 11 & Social media promotion & 0,046 & 3,25 & 0,15 \\
\hline 12 & Joint exhibitions & 0,049 & 3,50 & 0,17 \\
\hline 13 & Competence staff & 0,047 & 3,38 & 0,16 \\
\hline 14 & Have marketing team & 0,047 & 3,38 & 0,16 \\
\hline 15 & $\begin{array}{l}\text { Have partners/vendors } \\
\text { (entertainment, flower girl, } \\
\text { umbrella boy, videographer \& } \\
\text { photographer) }\end{array}$ & 0,049 & 3,50 & 0,17 \\
\hline 16 & Availability of homestays & 0,047 & 3,38 & 0,16 \\
\hline 17 & Quality of homestays & 0,037 & 2,63 & 0,10 \\
\hline & Weaknesses: & & & \\
\hline 1 & $\begin{array}{l}\text { Limited food and beverage } \\
\text { selection }\end{array}$ & 0,030 & 2,13 & 0,06 \\
\hline 2 & $\begin{array}{l}\text { Have camping ground but very } \\
\text { basic }\end{array}$ & 0,028 & 2,00 & 0,06 \\
\hline 3 & Difficulty in pricing & 0,032 & 2,25 & 0,07 \\
\hline 4 & Photo spots & 0,025 & 1,75 & 0,04 \\
\hline 5 & Public open space for waiting & 0,021 & 1,50 & 0,03 \\
\hline 6 & $\begin{array}{l}\text { Ability for personal selling to } \\
\text { prospective consumers }\end{array}$ & 0,028 & 2,00 & 0,06 \\
\hline 7 & Partner from travel agencies & 0,035 & 2,50 & 0,09 \\
\hline \multirow[t]{2}{*}{8} & $\begin{array}{l}\text { Training centre for asparagus } \\
\text { farming }\end{array}$ & 0,025 & 1,75 & 0,04 \\
\hline & & & & 2,88 \\
\hline
\end{tabular}

Based on the results of the summary analysis of internal factors as demonstrated in Table 1, the results of the multiplication of weights and ratings obtained by an overall total score was 2.88 .

2) Summary of External Factor Analysis (EFAS): According to the ranking and weighting of internal factors a score can be determined for a summary of external factor analysis (EFAS) based on the Table 2 .
TABLE II. EXTERNAL FACTOR ANALYSIS STRATEGY (EFAS)

\begin{tabular}{|c|c|c|c|c|}
\hline No & $\begin{array}{c}\text { External Factor Analysis } \\
\text { Strategy } \\
\end{array}$ & Weight & Rating & Score \\
\hline & Opportunities: & & & \\
\hline 1 & Bali security and safety & 0,106 & 2,75 & 0,29 \\
\hline 2 & Stable inflation & 0,121 & 3,13 & 0,38 \\
\hline 3 & $\begin{array}{l}\text { Development of communication } \\
\text { technology (software application) }\end{array}$ & 0,135 & 3,50 & 0,47 \\
\hline 4 & $\begin{array}{l}\text { Development of Information } \\
\text { Technology }\end{array}$ & 0,121 & 3,13 & 0,38 \\
\hline 5 & Community support & 0,155 & 4,00 & 0,62 \\
\hline \multirow[t]{2}{*}{6} & Local culture & 0,102 & 2,63 & 0,27 \\
\hline & Threats: & & & \\
\hline 1 & $\begin{array}{l}\text { Competitors with similar } \\
\text { products/attractions }\end{array}$ & 0,058 & 1,50 & 0,09 \\
\hline 2 & Similar products/attractions & 0,053 & 1,38 & 0,07 \\
\hline 3 & $\begin{array}{l}\text { Unpredictable political and } \\
\text { economic circumstances }\end{array}$ & 0,063 & 1,63 & 0,10 \\
\hline \multirow[t]{2}{*}{4} & Consumers' purchasing power & 0,082 & 2,13 & 0,17 \\
\hline & & & & 2,86 \\
\hline
\end{tabular}

Based on the results of the summary analysis of external factors as presented in Table 2, it can be seen that the results of the multiplication of weights and ratings obtained by an overall total score was 2.86 .

\section{Position of Pelaga Tourism Village}

After analysing the internal and external environment, the next step is to move the scores into the IFAS / EFAS matrix. In the previous calculation it was found that the weighted value at IFAS was 2.88. While the EFAS score is 2.86. The position of Pelaga Tourism Village is in position $\mathrm{V}$ on the internal external matrix. Based on Rauf [25] opinion, this shows that Pelaga Tourism Village is in a concentration strategy through horizontal integration or stability (there is no change in profit). Meaning that Pelaga Tourism Village is in a moderate attractive industry, the strategy should be relatively more defensive to avoid losing sales and profits. The companies in this position can expand markets, production facilities, and technology through internal and external development by either undertaking acquisitions or joint ventures with other tourism village. Accordingly, The Pelaga Tourism Village needs to increase sales by expanding the market to obtain more income. In addition, Pelaga Tourism Village should have conducted a concentration strategy through horizontal integration aims at avoiding or minimizing profit loss. The way in which to avoid sales decline at Pelaga Tourism Village is by strengthening the collaboration with the Badung Regency Government.

\section{E. Alternative Marketing Strategies for Tourism Potential of Pelaga Tourism Village}

Based on the internal and external environment of Pelaga Tourism Village, a SWOT (Strength, Weaknesses, 
Opportunities, and Threats) analysis has been conducted. The SWOT matrix produce four possible alternative marketing strategies. From each strategy, various kinds of marketing programs can be described supporting the marketing strategy of Pelaga Tourism Village. The SWOT analysis matrix of marketing strategies is as follows:

1) Strengths - Opportunities (SO) Strategy: Based on the opportunity and strength factors owned by Pelaga Tourism Village, four alternative SO strategies are introduced as follows.

a) Actively engaging websites and social media promotion: Social media has become one of the convenience media to find information for many people, this can be utilized by Pelaga Tourism Village in marketing and selling its products [26]. By regularly sharing information about the product, more likely the information will be conveyed to many people. YouTube, Instagram, and Facebook is becoming a trendy information provider, Pelaga Tourism Village has to make used of this platforms to promote tour packages by uploading all tourism potential videos includes testimonial from tourists.

b) Increasing the market to Australia, Japan, China and domestic: Increasing the list of dominant markets can be done by improving customer satisfaction during their visit, therefore they will become regular tourists. They are willing to promote and share information to their friends and relatives through their social media or else [27].

c) Utilizing social media channels: The promotional tools should be in multiple languages other than English or Indonesian such as Mandarin and Japan. The promotional tools should be shared in social media channels to reach wider target market. Social media has a crucial influence in travel planning [28, 29].

d) Enriching the tourism product selections (product diversification) [30]: For example, adding unique traditional dance as tourist attraction with the support from local community. Balinese culture embedded in tourism products without losing its uniqueness despite of globalization. The committee and local community have to work together to gain the benefits for all parties involved.

2) Strengths - Threats (ST) Strategy: The ST (StrengthsThreats) strategy is formulated by employing the strength of the Pelaga Tourism Village to overcome threats. The ST strategies are:

a) Make a list of competitors and set a competitive price: When deciding the price, the marketing and sales department should take into account the competitors' price [24]. The price has to be around the competitors because tourist tends to compare price.

b) Providing complimentary to visitors if they want to exclude an inclusion: The consumers should be given the opportunity to modify tour package to their convenience or given several tour alternatives. This is to avoid booking cancelation and change destination. Potential visitors will feel respected and more likely to spread positive word-of-mouth.

3) Weaknesses-Opportunities (WO) Strategy: The WO (Weaknesses-Opportunities) Strategy is formulated with the utilization of existing opportunities by minimizing the weaknesses of Pelaga Tourism Village. The WO strategy are:

a) Create a new tourism spot originated from Pelaga Tourism Village which difficult to imitate: Product differentiation is very important to attract visitors, mainly youngsters who seeks for instagram-able places.

b) The need for building a convenience waiting place for tour guides or drivers during tourists visit: Tour guides and drivers play important role to give suggestion to visit a destination. They have to be treated well.

4) Weakness-Threat (WT) Strategy: WT (WeaknessesTreats) Strategy. This strategy is based on activities to minimize existing weaknesses and avoid threats. Alternative strategies are:

a) Adding new and different tourism product: For example, developing Agro-tourism of coffee plantations, orange plantations, which are very suitable with the weather in the Pelaga Tourism Village area.

b) Improve payment regulations to avoid miscalculation affecting to income: Manage accountable payment system is very important to avoid fraud and corruption.

\section{CONCLUSION}

Pelaga Tourism Village has many tourism spots that are very potential to be improved for increasing community's welfare by proposing 7P marketing strategies of Kotler's. Based on the calculation of IFAS and EFAS factors, the position of Pelaga is in a concentration strategy through horizontal integration or stability (there is no change in profit). Horizontal integration is realized with Badung Regency Government in term of promotion collaboration. The promotion initiatives have to come from both parties. In order to improve sales, the main strategies of 7P's are: (1) to improve type of tour packages and establish new tourist attractions/products to invite tourist (product); (2) to set pricing alternatives to remain competitive (price); (3) to extend the promotional tools and strategies (promotion); (4), to build a rest area for tour guides/drivers (place); (5) to increase personal sales skill of Sales and Marketing staff (people); (6) to initiate collaboration between Tourism Village committee and local community to manage tourist satisfaction (process); and (7) to preserve the environment and surrounding (physical evidence).

\section{ACKNOWLEDGMENT}

The authors gratefully thank Bali State Polytechnic for funding this research with the Regular Competitive Scheme in 2020. Additionally, we also convey our gratitude to the Centre 
of Research and Community Service team with the assistance and advice during the research.

\section{REFERENCES}

[1] P. Jitpakdee, A. Harun and Z.B.M Zain, "Local community development through Community-Based Tourism Management: A case study of Mae Kampong Village," Mediterranean Journal of Social Sciences, vol. 7, pp. 407-414, 2016

[2] N. Kontogeorgopoulos, A. Churyen and V. Duangsaeng, "Success factors in Community-Based Tourism in Thailand: The role of luck, external support, and local leadership," Tourism Planning \& Development, vol. 11, pp. 106-124, 2014.

[3] N.I.K. Dewi, I.P. Astawa, I W Siwantara and I.G.A.B. Mataram, "Strategy development: Case study on two cultural villages in Bali," Journal of Advances in Humanities and Social Sciences, vol. 3, pp. 293 302, 2017.

[4] C.G. Sandbrook, "Local economic impact of different forms of naturebased tourism," Conservation Letters, vol. 3, pp. 21-28, 2010.

[5] C.P. Kumar, R. Sakthivel and H.N. Ramanathan, "Local people perceptions toward social, economic and environmental impacts of tourism in Kermanshah (Iran)," Asian Social Science, vol. 6, pp. 220225, 2010 .

[6] L. Anikasari, A. Haryono and S.H. Utomo, "Tourism village: Economic activity increases?" South East Asia Journal of Contemporary Business, Economics and Law, vol. 21, pp.163-168, 2020.

[7] M. Czajkowski, M. Giergiczny, J. Kronenberg and P. Tryjanowsk, "The economic recreational value of a white stork nesting colony: A case of 'stork village' in Poland," Tourism Management, vol. 40, pp. 352-360, 2014.

[8] C.P. Kumar, R. Sakthivel and H.N. Ramanathan, "Local residents perception and attitude towards model Tourism Village Kumbalangy Kerala," Journal of Contemporary Research in Management, vol. 8, pp. 59-67, 2013.

[9] D. Park, K. Lee, H. Choi and Y. Yoon, "Factors influencing social capital in rural tourism communities in South Korea," Tourism Management, vol. 33, pp. 1511-1520, 2012.

[10] I.M.S. Amerta, "The role of tourism stakeholders at Jasri Tourism Village development Karangasem Regency," International Journal of Social Sciences and Humanities, vol. 1, pp. 20-28, 2017

[11] V.M. Hieu and I. Rasovska, "Developing cultural tourism upon stakeholders' perceptions toward sustainable tourism development in Phu Quoc Island, Vietnam," Research and Science Today, no. 2, pp. 7186, 2017.

[12] N.I.K. Dewi, I.W. Siwantara, I. P. Astawa and I.G.A.B. Mataram, "Tourism supply chain framework: A case on tourism village," Advances in Social Science, Education and Humanities Research, vol. 83, pp. 211-217, 2019

[13] A. Hidayat, M. Rahmanita and H. Hermantoro, "Community empowerment in Plempoh Cultural Tourism Village," TRJ Tourism Research Journal, vol. 1, pp. 98-116, 2017.

[14] A.E. Cahyono, M.U. Kurniawan, Sukidin and S. Kantun, "Community empowerment models of tourism village based on superior commodities:
Realizing economic resilience," Journal of Distribution Science, vol. 1611 , pp. 29-36, 2018

[15] I.K. Suarja, I.N.M Rejeki and N.I.K. Dewi, "Development of potentialbased tourism models in Pelaga Tourism Village, Petang District Badung Regency," Advances in Social Science, Education and Humanities Research, vol. 354, pp. 173-176, 2019

[16] M. Saunders, P. Lewis and A. Thornhill, Research Methods for Business Students, 7th ed., Harlow: Pearson Education Limited, 2016, pp. $354-$ 495 .

[17] T.M.H Arif and M.Z. Hossin, "A comparative analysis of internal and external environments between Hotel Hyatt, UK and Hotel The Cox Today, Cox's Bazar, Bangladesh," IOSR Journal of Humanities and Social Science, vol. 21, pp. 13-22, 2016.

[18] U. Sosyal and A. Dergisi, "SWOT analysis: a theoretical review," The Journal of International Social Research, vol.10, pp. 994-1006, 2017.

[19] M.A.H. Sarker, W. Aimin and S. Begum, "Investigating the impact of marketing mix elements on tourists' satisfaction: An empirical study on East Lake," European Journal of Business and Management, vol. 4, pp. 273-282, 2012.

[20] R. Verma and S. Rathore, "Analysis of service marketing mix of Rajasthan a tourist destination," Asia Pacific Journal of Research, vol. 1, pp.66-71, 2018

[21] M.T. Khan, "The concept of marketing mix and its element," International Journal of Information, Business and Management, vol. 6, pp. 95-105, 2014

[22] M.J. Wolfe and J.C. Crotts, "Marketing mix modeling for the tourism industry: A best practices approach," International Journal of Tourism Sciences, vol. 11, pp. 1-15, 2011.

[23] A. Aliakbar, Z.S. Mojtaba and N. Mashaaallah, "A strategic marketing mix to tourist industry," Journal of Strategic Management Studies, vol. 1, pp. 49-68, 2010.

[24] E. Cirikoviv, "Marketing mix in tourism," Academic Journal of Interdisciplinary Studies, vol. 3, pp. 111-115, 2014.

[25] F.H.A. Rauf, "Environmental strategic factor analysis of the tourism industry in the South Coastal part of Sri Lanka," Journal of Emerging Trends in Economics and Management Sciences (JETEMS), vol. 5, pp. 426-434, 2014.

[26] S. Hays, S. Page and D. Buhalis, "Social media as a destination marketing tool: An exploratory study of the use of social media among National Tourism Organisations," Current Issues, vol. 16, pp. 211-239, 2012.

[27] E. Vladi, "Tourism development strategies, SWOT analysis and improvement of Albania's image," European Journal of Sustainable Development, vol. 3, pp. 167-178, 2014.

[28] W. Lange-Faria and S. Elliot, "Understanding the role of social media in destination marketing," Tourismos: An International Multidisciplinary Journal of Tourism, vol. 7, pp. 193-211, 2012.

[29] R. Minazzi, Social media marketing in tourism and hospitality. New York: Springer, 2015. pp 47-71.

[30] A.M. Benur and B. Bramwell, "Tourism product development and product diversification in destinations," Tourism Management, vol. 50, pp. 213-224, 2015. 